Journal of Mechanical Engineering and Sciences

ISSN (Print): 2289-4659; e-ISSN: 2231-8380

Volume 12, Issue 4, pp. 4180-4190, December 2018

(C) Universiti Malaysia Pahang, Malaysia

DOI: https://doi.org/10.15282/jmes.12.4.2018.14.0360

\title{
Machinability and related properties of austempered ductile iron: A review
}

\author{
Ananda Hegde ${ }^{1}$, Sathyashankara Sharma ${ }^{1 *}$ and Gowri Shankar M.C ${ }^{1}$ \\ ${ }^{1}$ Department of Mechanical and Manufacturing Engineering, Manipal Institute of \\ Technology, Manipal Academy of Higher Education, \\ Manipal, Karnataka, India, 576104 \\ Phone: +9740540928; Fax: +91-820-2571071 \\ *Email: ss.sharma@manipal.edu
}

\begin{abstract}
When the ductile iron which is also known as Spheroidal Graphite (SG) iron, is subjected to austempering heat treatment, the material is known as austempered ductile iron (ADI). This material has good mechanical properties and has various applications in different fields. This revolutionary material with its excellent combination of strength, ductility, toughness and wear resistance has the potential to replace some of the commonly used conventional materials such as steel, aluminium and other light weight alloys as it offers production advantage as well. One of the problems encountered during manufacturing is machining of ADI parts owing to its high hardness and wear resistance. Many researchers over a period of time have reported the machinability aspects of the ADI. This paper presents a review on the developments made on the machinability aspects of ADI along with other mechanical properties.
\end{abstract}

Keywords: Machinability; Austempered ductile iron; Austenitization; Austempering.

\section{INTRODUCTION}

Ductile cast iron which is also known as Spheroidal Graphite (SG) iron is a type of cast iron with better ductility compared to the other types of cast iron. When the austempering heat treatment is carried out on the ductile iron, the material is known as austempered ductile iron (ADI). Austempered ductile iron has good mechanical properties because of its unique microstructure "ausferrite" which is shown in the Figure 1. This microstructure consists of ferrite, austenite and graphite nodules. Ferrite is in acicular shape whereas austenite is rich in carbon. ADI has great strength, high hardness with good ductility and toughness [1-6]. ADI has good strength to weight ratio. It is nearly $10 \%$ less dense than steel [7-9]. The cost associated with this material is also less because of the simple casting method. This engineering material offers the design engineers the economical benefit as it is available at lesser cost. Other mechanical properties of this material, such as wear resistance and fatigue strength are also higher [9]. Because of this superior combination of mechanical properties and lesser cost, ADI has wide range applications such as structural application, automotive industry and farm machinery [10-13]. 


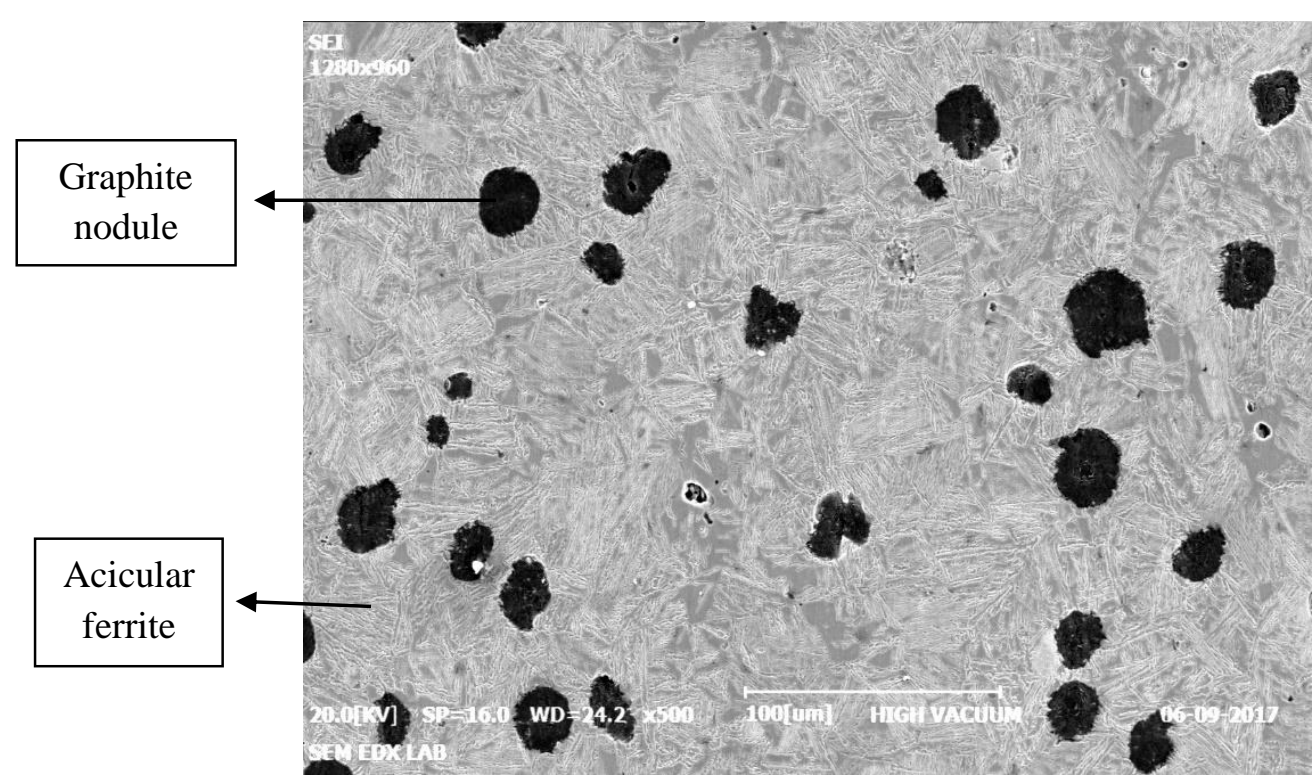

Figure 1. Microstructure of ADI.

By controlling and varying the heat treatment process parameters, chemical composition, casting size and shape, mechanical properties of the material can be altered. Table 1 shows the mechanical properties of different grades of ADI.

Table 1. Mechanical properties of different grades of ADI [14].

\begin{tabular}{ccccc}
\hline Grade & $\begin{array}{c}\text { Tensile strength } \\
(\mathrm{MPa})\end{array}$ & $\begin{array}{c}\text { Yield strength } \\
(\mathrm{MPa})\end{array}$ & $\begin{array}{c}\text { Elongation } \\
(\%)\end{array}$ & $\begin{array}{c}\text { Hardness } \\
(\mathrm{BHN})\end{array}$ \\
\hline 1 & 900 & 550 & 9 & 302 \\
2 & 1050 & 700 & 7 & 340 \\
3 & 1200 & 850 & 4 & 387 \\
4 & 1400 & 1100 & 2 & 418 \\
5 & 1600 & 1300 & 1 & 460 \\
\hline
\end{tabular}

Classification of ADI into various grades is based on the mechanical properties of the material. Grade 5 ADI offers the maximum tensile strength and hardness. However, ductility of this grade is lower compared to other grades. Grade 1 offers excellent ductility with minimum strength and hardness. Based on the requirement for the application, suitable grade ADI has to be selected.ADI is produced by the austempering heat treatment which consists of two steps. A typical heat treatment cycle for the production of ADI is shown in the Figure 2.

Process A - B represents the initial heating of the specimen to the austenitization temperature. This process is known as austenitization. The exact temperature to which the specimen is heated depends on many factors such as chemical composition, size and shape of the specimen. Specimen is held at this temperature for certain time so as to get the fully austenitic matrix (process B - C). After holding the specimen at the austenitization temperature for the fixed time, it is rapidly transferred to a salt bath which is maintained at the austempering temperature (process $\mathrm{C}$ - D). This process is known as austempering and the temperature is in the range $250-420^{\circ} \mathrm{C}$. Specimen is held at that temperature for predetermined time (process D - E). It is finally air cooled to the room 
temperature (process $\mathrm{E}-\mathrm{F}$ ). This ensures the unique microstructure to the ductile iron which is known as "ausferrite". Holding time at the austempering temperature is very important as it decides the final microstructure of the material. The first reaction which takes place during the austempering is the decomposition of austenite into acicular ferrite and carbon rich austenite. If the sample is held at the same temperature for more time, then the second reaction occurs in which carbon rich austenite decomposes into ferrite and carbide. This is not desirable as it degrades the mechanical properties of the material as it embrittles the material [15-17]. The austempering time should be such that it should be sufficient to complete the first reaction, but it should not initiate the second reaction. This time range is called as "process window".

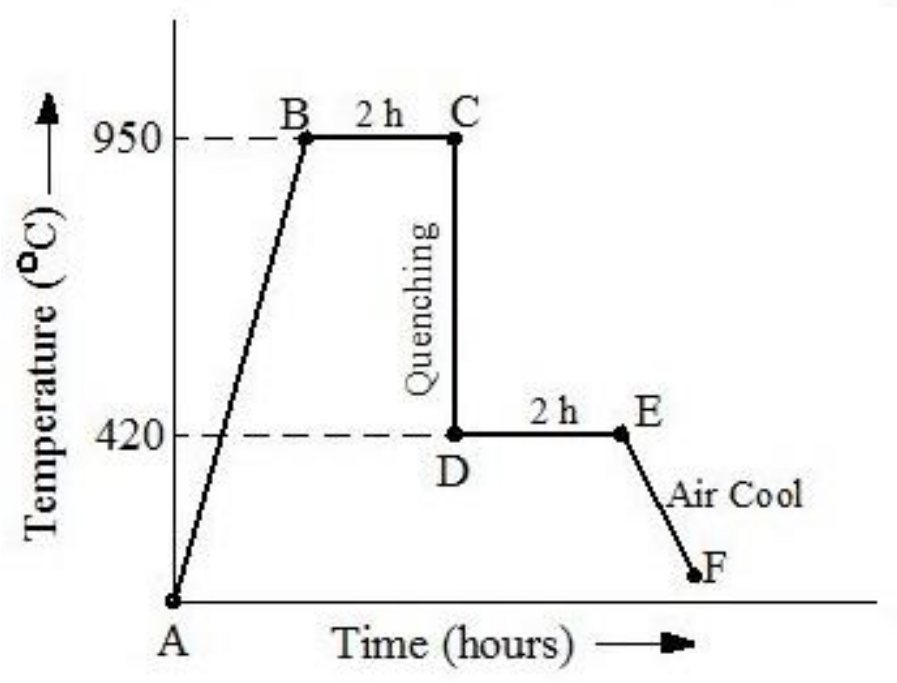

Figure 2. Typical heat treatment cycle for ADI .

The only concern associated with the ADI is the machining of this material, especially post heat treatment. Because of the high hardness and strength, there is a possibility of phase transformation from austenite to martensite because of the induced strain during machining [18-20]. This is usually determined by calculating the amount of each phase present in the material using the $\mathrm{X}$ - ray diffraction method [21]. This transformation severely reduces the tool life and in turn machinability. Even though it is suggested to machine the ADI prior to the heat treatment [28-31], there are several instances in which it is necessary to machine it post heat treatment. Various alloying elements present, heat treatment parameters and the selection of machining parameters greatly affect the machinability of ADI. This review article discusses the recent work carried out on the machinability and the developments happened over the recent past years. 


\section{EFFECT OF ALLOYING ELEMENTS ON ADI}

Various alloying elements are added to the ductile iron in order to increase the hardnenability of the material. Commonly added alloying elements are $\mathrm{Mo}, \mathrm{Mn}, \mathrm{Cu}$ and $\mathrm{Ni}$ which help to increase the austemperability by avoiding the pearlite formation while cooling the material from austenitization temperature to austempering temperature [22]. Some of the alloying elements like copper and nickel help in increasing the width of the processing window for austempering reaction [23]. It is very important to carefully select the optimum level of alloying elements so that any adverse effect of these elements on the mechanical properties can be prevented. This mainly depends on casting section thickness, composition of the material and characteristics of the selected heat treatment process. The details regarding the effect of various alloying elements are discussed below.

\section{Manganese}

Hardenability of the material and the stability of austenite improves by the addition of manganese to the ADI. However, there is a concern regarding the addition of higher amount manganese to the ADI as it segregates to the intercellular regions and precipitates the carbides. This adversely affects the mechanical properties of the ADI especially leading to the reduction of ductility. Bayati et al. [24] studied the austempering kinetics in the ADI alloyed with $0.67 \mathrm{wt} \%$ manganese. It was found that austempering reaction gets delayed because of the high amount of manganese in the material. It is also reported that high strength can be achieved by austenitizing at a lesser temperature of $920^{\circ} \mathrm{C}$. But, at this condition, high ductility grades cannot be achieved. Murthy et al. [25] reported about the abrasion and erosion behaviour of manganese alloyed ADI. Manganese was added in three different proportions of $1 \%, 2 \%$ and $3 \mathrm{wt} \%$ and superior wear (abrasion and erosion) result was obtained for $2 \mathrm{wt} \%$ manganese alloyed ADI. This was attributed the high nodule count obtained for this condition. It is reported by Hamid and Elliott [26] that a processing window which is closed at the high austempering temperature of $375^{\circ} \mathrm{C}$ to $400{ }^{\circ} \mathrm{C}$ can be opened by austenitizing it at low temperature of $870^{\circ} \mathrm{C}$ to $920^{\circ} \mathrm{C}$.

\section{Molybdenum}

Molybdenum is the alloying element which is used mainly to improve the hardenability. However, similar to manganese, this element adversely affects the mechanical properties of ADI if used in excess. Molybdenum segregates to the intercellular regions to form carbides if excess amount of it used in the ADI [27]. Klocke et al. [28] reported that use of more than $0.3 \mathrm{wt} \% \mathrm{Mo}$, adversely affect the tool life and there is a risk of breakout of the cutting edge as the crater wear increases.

\section{Copper}

Copper is the less effective hardenability improvement alloying element. Eric et al. [32] reported that copper does not have significant effect on the tensile properties while it increases the ductility at lower austempering temperature of $350^{\circ} \mathrm{C}$ [33].

\section{Nickel}

Nickel is used to improve the hardenability of the ADI. Up to $2 \mathrm{wt} \%$ nickel may be used to improve the hardenability [34]. Jagmohan and Batra [35] reported that cutting force of ADI increases as the nickel content increases at a particular austempering temperature. 


\section{MACHINABILITY ASPECTS OF ADI}

Even though ADI offers good mechanical properties, researchers have concern regarding its machinability as the hardness and tensile strength of this material are very high. Relative machinability of ADI in comparison to other materials is shown in Figure 3. It is seen that ADI cannot be easily machined as other material such as ferritic or pearlitic ductile iron.

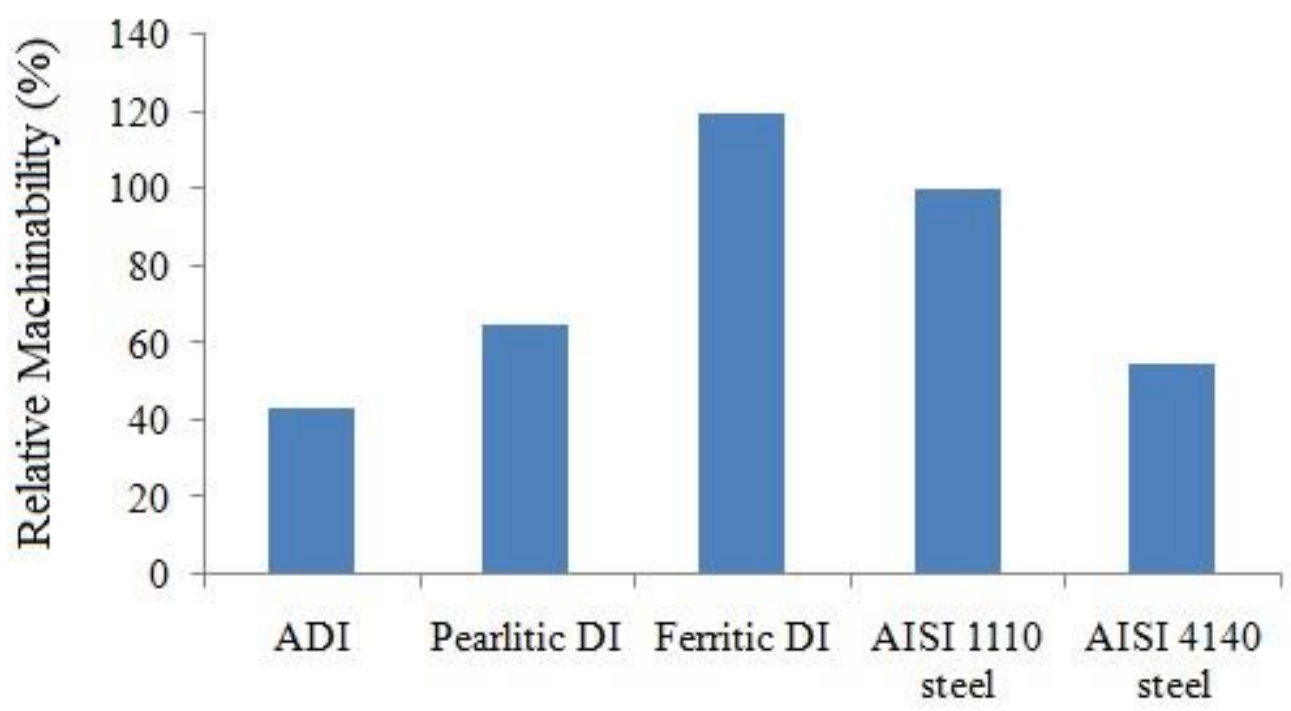

Figure 3. Relative machinability of various materials.

It is suggested to machine the ADI prior to heat treatment whenever possible. In the case of post heat treatment machining, these is a possibility of strain induced transformation of austenite to martensite. The carbon rich austenite is metastable and when ADI is subjected to plastic deformation, high carbon austenite may transform into martensite which is a hard and brittle phase. This transformation severely affects the tool life [3638]. Therefore, selection of appropriate heat treatment parameters and the machining parameters are of paramount importance to obtain the optimum machinability.

Cakir and Isik [39] reported the machinability results for the samples which have been austempered at various temperature and time. Experiments were conducted according to the machining standard ISO 3685 [40] in order to assess the tool life. Carbide inserts of specification ISO SNMG 120408 were used to machine the samples. No coolant was used during the machining. It is reported that the higher machinability in terms of tool life, was obtained for the samples austempered at $400^{\circ} \mathrm{C}$ for $1 \mathrm{~h}$. Lower austempering temperature of $300^{\circ} \mathrm{C}$ has produced some uncommon results. Samples with lesser hardness caused the greater tool wear. This was attributed to the formation of built up edge because of the inappropriate selection of cutting speed.

Manivel and Gandhinathan [41] have carried out the machinability tests on grade 3 austempered ductile iron. Cutting parameters are optimized for better tool life and surface finish. Turning operations were carried out at dry condition. CVD coated carbide cutting inserts were used to carry out the machining. Cutting speed, feed, depth of cut and nose radius are selected as the factors at different levels. Machinability test results have shown that cutting speed is the major contributing factor on tool life as well as on surface 
roughness. Tool wear obtained with the nose radius of $0.4 \mathrm{~mm}$ was minimum. However, surface finish obtained with the nose radius of $0.4 \mathrm{~mm}$ was not good compared to the surface finish obtained with the nose radius of $0.8 \mathrm{~mm}$. Cutting speed of $100 \mathrm{~m} / \mathrm{min}$, feed rate of $0.12 \mathrm{~mm} / \mathrm{rev}$ and depth of cut $0.3 \mathrm{~mm}$ produced the optimum tool life.

Seker and Hasirci [42] reported the machinability results for copper and nickel alloyed ADI. Different proportion of copper and nickel were added to the ADI. Austenitization was carried out at $900^{\circ} \mathrm{C}$ for $90 \mathrm{~min}$. Austempering was carried out at $370^{\circ} \mathrm{C}$ for different time duration of $60,90,180$ and 200 min. Machining tests were conducted using cemented carbide tool of SCMT 12M508E. Machinability was assessed in terms of surface roughness and cutting force. Results have shown that increasing the austempering time from $60 \mathrm{~min}$, did not have any significant effect on machinability. It is also reported that better surface roughness and cutting force were obtained for the as cast specimen alloyed with $0.7 \mathrm{wt} \%$ copper and $0.7 \mathrm{wt} \%$ nickel.

Carvalho et al. [43] reported about the machining characteristics of grade 2 and grade 3 austempered ductile iron. Heat treatment was carried out choosing the parameters carefully in order to obtain Grade 2 and Grade 3 ADI. Machining tests were carried out using carbide inserts WNMA 080408-KR 3215. Machining was carried out with the use of cutting fluid to reduce the cutting temperature. Cutting speed was set at $120 \mathrm{~m} / \mathrm{min}$ and feed rate at $0.1 \mathrm{~mm} / \mathrm{rev}$. The results have shown that a lower tool life was obtained for grade 2 ADI compared to the tool life obtained for grade 3 ADI at the same cutting parameters. This result was attributed to the fact that different wear mechanism in grade 2 and grade 3 ADI. Minimum surface roughness value of Ra, $0.3 \mu \mathrm{m}$ was obtained for grade $3 \mathrm{ADI}$ while using the tool with a nose radius of $1.6 \mathrm{~mm}$.

Klocke et al. [28] reported the machinability aspects of molybdenum alloyed ADI. The results have shown that tool life is not affected by the austempering time from 60 min to $180 \mathrm{~min}$. ADI which was alloyed with molybdenum content of more than $0.3 \mathrm{wt}$ $\%$, has resulted in the reduction of average tool life.

Seah and Sharma [44] reported about the machining characteristics of austempered ductile iron alloyed with nickel. Machinability was assessed in terms of machinability index. It is reported that, as the austempering temperature increased, machinability index was also increased because of the severe drop in the hardness. Nickel content had only marginal effect on the hardness.

Meena and Mansori [45] investigated the dry drilling of ADI. Grade 1 austempered ductile iron was subjected to dry drilling operation using PVD coated carbide tools. Machining was carried out at various speed and feed rates. The results have shown that combination of low feed rate and high cutting speed resulted in higher cutting force. The influence of cutting speed on the surface finish was more compared to that of feed rate. Lower cutting speed produced high value of surface roughness because of the formation of built up edges.

Polishetty et al. [46] reported about the machining characteristics of austempered ductile iron when the feed rate was varied in different levels. Drilling operation was carried out to assess the effect of feed rate on cutting force while keeping speed and depth of cut at the constant values. Grade 1200 and grade 1400 ADI were used for the experiments. Depth of cut was kept constant at $25 \mathrm{~mm}$ and speed at $45 \mathrm{~m} / \mathrm{min}$. No coolant was used during drilling. Two different feed rate values of 0.2 and $0.35 \mathrm{~mm} / \mathrm{rev}$ were used. The results have shown that increase in the cutting force as the feed rate increased. Also, there was no indication of strain induced transformation at the lower feed rate of $0.2 \mathrm{~mm} / \mathrm{rev}$. However, at the higher feed rate of $0.35 \mathrm{~mm} / \mathrm{rev}$, there was strain induced transformation of austenite to martensite along certain locations at the hole boundary. 
Kataku et al. [47] studied about the machining of grade 2 austempered ductile iron with various cutting seed. Dry turning operation was carried out using polycrystalline cubic boron nitride (PCBN) tool. Depth of cut of $0.2 \mathrm{~mm}$ and feed rate of $0.05 \mathrm{~mm} / \mathrm{rev}$ were used for machining. Speed was varied from 50 to $800 \mathrm{~m} / \mathrm{min}$. The results have shown that abrasion wear was the main wear mechanism for cutting speeds less than $150 \mathrm{~m} / \mathrm{min}$. At higher cutting speed, shear localization was the major factor controlling the wear rate. Cutting speed range of $150-500 \mathrm{~m} / \mathrm{min}$ was found to be optimum range for machining. Aslantas and Ucun [48] studied about machining of austempered ductile iron using different cutting tools. Ductile irons were austempered at various temperatures. Turning operations were carried out on CNC machine using ceramic and cermet cutting tools with geometry of CNGA 120404TIN22 and CNMG 120404- NF IC530N respectively. Constant feed rate of $0.1 \mathrm{~mm} / \mathrm{rev}$ and depth of cut $1 \mathrm{~mm}$ were used for turning operation. Speed was varied from $100-500 \mathrm{~m} / \mathrm{min}$. No cutting fluid was used while carrying out the machining. The results have shown that lower cutting force was obtained at the higher austempering temperature. While using the cermet cutting tool, it was reported that cutting force decreases as the cutting speed increased. There was no significant variation of cutting force while using the ceramic tool. At the higher cutting speed better surface finish was obtained with cermet tool. It is reported that wear on tool occurs faster in cermet cutting tool compared to ceramic tool for a cutting speed of $340 \mathrm{~m} / \mathrm{min}$. It was recommended to use cermet tool for machining ADI with low cutting speed.

Brandenberg [49] reported about the successful machining of ADI. It is recommended to use the deeper depth of cut value to overcome the problems caused because of the strain induced transformation of austenite to martensite during machining. This allows the cutting surface to cut below the martensite region. Whenever possible, rough machines should be carried out prior to heat treatment. It is reported that $\mathrm{K}$ grade carbide tools may be used while machining the ADI with the use of cutting fluid. For continuous cut processes, $\mathrm{Al}_{2} \mathrm{O}_{3}$ ceramic tool may be used. $\mathrm{P}$ grade tools are suggested for dry machining.

Datt and Batra [35] reported about the machinability aspects of nickel alloyed ADI. Nickel content was varied at different levels of $0,0.1,0.3$ and $0.6 \mathrm{wt} \%$. Austempering treatment was carried out at different temperatures from $270^{\circ} \mathrm{C}$ to $420^{\circ} \mathrm{C}$. Milling tests were carried out to assess the machinability in terms of cutting force, machinability index and surface quality. The results have shown that least cutting force was obtained for ADI without nickel content. It was reported that cutting force decreases as the austempering temperature was increased for all the nickel alloyed ADI. The ADI alloyed with $0.6 \mathrm{wt} \%$ nickel, austempered at $420^{\circ} \mathrm{C}$ for $120 \mathrm{~min}$ has shown the best machinability among all samples.

Carvalho et al. [50] reported about the machining of austempered ductile iron by varying the cutting parameters in different levels. Three different grades of ADI were subjected to machining operation using the carbide tool designed for roughing turning process. The results have shown that higher feed rates resulted in greater material removal rate with acceptable tool life which is helpful for increasing the productivity. Better machinability in terms of tool life was obtained for grade 3 ADI with higher feed rate compared to grade $2 \mathrm{ADI}$ with lower feed rate. It is reported that lower cutting speed of $60 \mathrm{~m} / \mathrm{min}$ resulted in better tool life.

Avishan et al. [51] studied the machining of austempered ductile iron with varying the depth of cut values. Ductile iron alloyed with copper, nickel and molybdenum was austempered at different temperatures of $300^{\circ} \mathrm{C}, 340^{\circ} \mathrm{C}$ and $375^{\circ} \mathrm{C}$. Machining tests were conducted at three different levels of depth of cut at 0.1, 0.5 and $1 \mathrm{~mm}$. Cutting speed was 
kept constant at $116 \mathrm{~m} / \mathrm{min}$. Machining was carried out using CVD coated tools. Tool life obtained with the lower depth of cut was not minimum. 0.5 and $1 \mathrm{~mm}$ depth of cut produced better machiability compared to machiability at $0.1 \mathrm{~mm}$ of depth of cut. It is recommended to use deeper depth of cuts for machining low alloyed ADI.

Isik [52] reported about the machinability of austempered ductile iron when it was machined using ceramic and carbide cutting. Ductile iron was austenitized at $927^{\circ} \mathrm{C}$ and austempered at $400^{\circ} \mathrm{C}$ for $1 \mathrm{~h}$ duration. Machining tests were carried out according to ISO 3685 standard. Two different types of cutting inserts were used to machine ADI. TiN (PVD) coated KY4400 ceramic and CVD coated carbide ISO P25 inserts were used. Turning operation was carried out with feed rate of $0.12 \mathrm{~mm} / \mathrm{rev}$, depth of cut $1 \mathrm{~mm}$. Different speed values were used. At the higher cutting speed, PVD coated ceramic cutting tool resulted in longer tool life compared to the CVD coated carbide tool. Better surface finish was obtained with the use of carbide tool.

\section{SUMMARY}

ADI has good mechanical properties, but its machinability is a great concern for the researchers. The main problem faced during the machining of ADI is the strain induced transformation of austenite to martensite phase which reduces the tool life significantly. It is very important to restrict the amount of alloying elements added especially manganese and molybdenum in order to prevent strain induced transformation during machining. High nodule count is always preferred as it prevents the strain induced transformation. Higher depth of cut is preferred as it helps to machine efficiently in the case of strain induced transformation. Even though there is a great concern regarding the machinability of ADI, by selecting the appropriate tool with appropriate machining parameters, ADI can be machined successfully.

\section{REFERENCES}

[1] Nofal A, Jekova L. Novel processing techniques and applications of austempered ductile Iron. Journal of the University of Chemical Technology and Metallurgy 2009; 44: 213-228.

[2] Imasogie BI. Microstuctural features and mechanical properties of compacted graphite iron treated with calcium-magnesium based master alloy. Journal of Materials Engineering and Performance 2003; 12 (3): 239-243.

[3] Kovacs BV. Austempered ductile iron: fact and fiction. Modern Casting 1990; 3: $38-41$.

[4] Moore DJ, Rouns TN, Rundman KB. The relationship between microstructure and tensile properties in ADI. American Foundry Society 1987; 95:765-774.

[5] Kovacs B, Keough J. Physical properties and application of austempered gray iron. Report No. AFS 93-141. America Foundry Society Transactions 1993; 283291.

[6] Voigt RC, Loper CR. Austempered ductile iron-process control and quality assurance. Journal of Heat Treating 1984; 3 (4): 291-309.

[7] Putatunda SK, Gadicherla PK. Examination influence of austenitising temperature on fracture toughness of a low manganese austempered ductile iron (ADI) with ferritic as cast structure. Materials Science and Engineering A 1999; 268: 15-31. 
[8] Ashwin P, Guy LE. A comparative assessment of austempered ductile iron as a substitute in weight reduction application. Proceedings of the 2008 International Manufacturing Science and Engineering Conference MSEC2008/ICMP2008; 4957.

[9] Nofal A. Advances in the metallurgy and applications of ADI. Journal of Metallurgical Engineering 2013; 2: 1-18.

[10] Yuichi T, Hidehiko K. Forced development and application of austempered spheroidal graphite cast iron. Materials Transactions 1992; 33 (6): 534-557.

[11] Zimba J, Simbi DJ, Navara E. Austempered ductile iron: an alternative material for earth moving components. Cement and Concrete Composites 2003; 25 (6): 643-649.

[12] Kovacs BV. Development of austempered ductile iron (ADI) for automobile crankshafts. Journal of Heat Treating 1987: 5: 55-60.

[13] Bixler C, Hayrynen K, Keough J, Pfaffmann G, Gledhill S. Locally austempered ductile iron (ladi). SAE International Journal of Materials and Manufacturing 2010: 3 (1): 380-390.

[14] ASTM A897/ A897M-16, Standard Specification for Austempered Ductile Iron Castings, Annual Book of ASTM Standards, Vol. A 04.02, ASTM International, West Conshohocken, PA (2016).

[15] James DM. A design engineer's digest of ductile iron, 8th ed., Sorelmetal Technical Services Rio Tinto Iron \& Titanium, Inc., London, 2005.

[16] Swain SK, Panda RK, Dhal JP, Mishra SC, Sen S. Phase investigation of austempered ductile iron. Orissa Journal of Physics 2012; 19 (1): 73-80.

[17] Yang J, Putatunda, SK. Influence of a novel two-step austempering process on the strain-hardening behavior of austempered ductile cast iron (ADI). Materials Science and Engineering A 2004; 382: 219-230.

[18] Yescas MA, Bhadeshia HK, MacKay DJ. Estimation of the amount of retained austenite in austempered ductile irons using neural networks. Materials Science and Engineering A 2001; 311: 162-173.

[19] Daber K, Rao P. Formation of strain-induced martensite in austempered ductile iron. Journal of Materials Science 2008; 43:357-367.

[20] Polishetty A. Machinability and microstructural studies on phase transformation in adi. A PhD thesis submitted to Auckland University of Technology in fulfilment of the requirements for the degree of Doctor of Philosophy, 2011.

[21] Aranzabal J, Gutierrez I, Rodriguez-ibabe JM, Urcola JJ. Influence of the amount and morphology of retained austenite on the mechanical properties of an austempered ductile iron. Metallurgical and Materials Transactions A 1997; 28(5): 1143-1156.

[22] Jiwang GM, Tyrala E, Lopez HJ. Effect of copper and nickel on the transformation kinetics of austempered ductile iron. Journal of Materials Engineering and Performance 2014; 23 (10): 3505-3510.

[23] Bahmani M, Elliot R. Isothermal transformation diagrams for alloyed ductile cast iron. Materials Science and Technology 1994; 10 (12): 1050-1056.

[24] Bayati H, Elliot R, Lorimer GW. Influence of austenitising temperature on austempering of high manganese alloyed ductile iron. Materials Science and Technology 1995; 11 (8): 776-786.

[25] Narasimha KM, Sampathkumaran P, Seetharamu S. Abrasion and erosion behaviour of manganese alloyed permanent moulded austempered ductile iron. Wear 2009; 267 (9-10): 1393-1398. 
[26] Hamid AS, Elliot R. Influence of austenitising temperature on austempering of an mn-mo-cu alloyed ductile iron. Materials Science and Technology 1997; 13 (12): 24-29.

[27] Bahmani M, Elliot R, Varahram N. Austempered ductile iron: a competitive alternative for forged induction-hardened steel crankshafts. International Journal of Cast Metals Research 1997; 9 (5): 249-257.

[28] Klocke F, Arft M, Lung D. Material-related aspects of the machinability of Austempered Ductile Iron. Production Engineering 2010; 4 (5): 433-441.

[29] Tahir M, Ghani J, Nuawi M, Rizal M, Haron C. Flank wear and I-kaz 3D correlation in ball end milling process of Inconel 718. Journal of Mechanical Engineering and Sciences 2015; 9: 1595-1603.

[30] Pujara J, Kothari K, Gohil A. An investigation of material removal rate and kerf on WEDM through grey relational analysis. Journal of Mechanical Engineering and Sciences 2018; 12 (2): 3633-3644.

[31] Razak N, Rahman M, Kadirgama K. Cutting force and chip formation in end milling operation when machining nickel based superalloy, Hastelloy C-2000. Journal of Mechanical Engineering and Sciences 2017; 11(1): 2539-2551.

[32] Eric O, Rajnovic D, Sidjanin, Zec S, Jovanovic MT. An austempering study of ductile iron alloyed with copper. Journal of the Serbian Chemical Society 2005; 70 (7): 1015-1022.

[33] Ranjan KD, Dipak KM, Ajith KC. Evolution of microstructures during austempering of ductile irons alloyed with manganese and copper. Metallurgical and Materials Transactions A 2013; 44: 1376 - 1387.

[34] Uma B, Subrata R, Prabhakar SR. Impact properties of copper alloyed and nickel copper alloyed ADI. Journal of materials Engineering and Performance 2006; 16 : $485-489$.

[35] Jagmohan D, Batra U. Influence of composition and austempering temperature on machinability of austempered ductile iron. Journal of Chemical, Molecular, Nuclear, Materials and Metallurgical Engineering 2013; 7 (2): 116- 121.

[36] Sosa AD, Echeverría MD, Moncada OJ. Machining and heat treatment effects on distortion and residual stresses in an industrial application of ADI. ISIJ International 2004; 44 (7): 1195- 1200.

[37] Garin JL, Mannheim RL. Strain-induced martensite in ADI alloys. Journal of Materials Processing Technology 2003; 143: 347-351.

[38] Aslantas K, Ucum I. The performance of ceramic and cermet cutting tools for the machining of austempered ductile iron. The International Journal of Advanced Manufacturing Technology 2009; 41 (7): 642-650.

[39] Cemal MC, Yahya I. Investigating the machinability of austempered ductile irons having different austempering temperatures and times. Materials and Design 2008; 29 (5): 937- 942.

[40] ISO 3685: 1993 (E) Tool-life testing with single point tools 1993.

[41] Manivel D, Gandhinathan R. Optimization of surface roughness and tool wear in hard turning of austempered ductile iron (grade 3) using taguchi method. Measurement 2016; 93: 108-116.

[42] Ulvi S, Hasan H. Evaluation of machinability of austempered ductile irons in terms of cutting forces and surface quality. Journal of Materials Processing Technology 2006; 173 (3): 260-268. 
[43] Marcelo DC, Davi MM, Jefferson OG. An analysis of the machinability of ASTM grades 2 and 3 austempered ductile iron. Journal of Materials Processing Technology 2013; 213 (4): 560-573.

[44] Seah KH, Sharma SC. Machinability of alloyed austempered ductile iron. International Journal of Machine Tools and Manufacture 1995; 35 (10): 14751479.

[45] Meena A, Mansori EI. Specific cutting force, tool wear and chip morphology characteristics during dry drilling of austempered ductile iron (ADI). The International Journal of Advanced Manufacturing Technology 2013; 69 (9): 28332841.

[46] Ashwin P, Guy L, Timotius P. A case study on effect of feed rate on machinability of austempered ductile iron. Advanced Materials Research 2013; 748: 247-251.

[47] Katuku K, Koursaris A, Sigalas I. Wear, cutting forces and chip characteristics when dry turning astm grade 2 austempered ductile iron with pcbn cutting tools under finishing conditions. Journal of Materials Processing Technology 2009; 209 (5): 2412-2420.

[48] Kubilay A, Irfan U. The performance of ceramic and cermet cutting tools for the machining of austempered ductile iron. The International Journal of Advanced Manufacturing Technology 2009; 41 (7): 642-650.

[49] Brandenberg K. Successfully machining of austempered ductile iron. Applied Process Inc. Technologies Div. - Livonia, Michigan, USA, 2011.

[50] Vasconcelos MC, Gomes J, Melo D. The influence of the cutting parameters at the tool life when turning adi under roughing conditions. 21st brazilian congress of mechanical engineering, October-24-28, 2011, Natal, RN, Brazil, 2011.

[51] Avishan B, Yazdani S, Vahid D. The influence of depth of cut on the machinability of an alloyed austempered ductile iron. Materials Science and Engineering A 2009; 523: 93-98.

[52] Yahya I. The performance evaluation of ceramic and carbide cutting tools in machining of austemepered ductile irons. Uludağ University Journal of The Faculty of Engineering 2014; 19 (2): 67-76. 